\title{
LIFESTYLE TRENDS AND HOUSING TYPOLOGIES IN EMERGING MULTICULTURAL CITIES
}

\author{
Ashraf M. SALAMA ${ }^{\mathrm{a}}$, Florian WIEDMANN ${ }^{\mathrm{b}}$, Hatem G. IBRAHIMc \\ a University of Strathclyde, Glasgow, United Kingdom of Great Britain and Northern Ireland \\ b, cQatar University, Doha, Qatar \\ E-mails: ${ }^{a} a s h r a f . s a l a m a @ s t r a t h . a c . u k ;{ }^{b}$ wiedmann.f@gmail.com (corresponding author); \\ chatem_ibrahim@qu.edu.qa
}

Received 13 April 2017; accepted 30 August 2017

\begin{abstract}
The introduction of new housing typologies in emerging cities is rooted in dynamics including infrastructural investments, urban growth rates and new development policies. In accommodating new lifestyles, demand-driven patterns by tenants and property owners are the main factors consolidating development trends in future. This paper explores the relationship between new lifestyle patterns and housing typologies in emerging cities. Within the context of Gulf cities, namely Dubai, Abu Dhabi, Doha and Manama, this paper investigates demographic structures and housing trends where a rapid phase of urban growth has transformed local urbanism. Current social structures were analysed by following a new 'lifestyle framework' resulting in the characterization of four main lifestyle trends. This is coupled with the assessment of 240 cases of new residences from the Gulf cities under study. The juxtaposition of both studies offers an outlook relevant to the importance of a transition from supply-driven to demand-driven housing dynamics to accommodate emerging multicultural societies. The paper thus contributes to a better understanding and identification of the social groups that are currently lacking suitable housing.
\end{abstract}

Keywords: housing typologies, lifestyle trends, real estate, Gulf cities, urban transformation.

\section{Introduction}

Since the beginning of modern globalization cities have entered a fierce competition to attract investment in order to transform into key hubs within expanding networks. In 1976 Harvey Molotch described the new roles of cities as "growth machines" (Molotch 1976). While cities in highly industrialized countries benefited from already existing infrastructure, their large size and thus established local markets, cities in emerging countries needed to initiate new development strategies in order to attract urban growth since the end of the $20^{\text {th }}$ century in order to compete. This growth resulted in rapid urbanization processes and the mass migration of new inhabitants. Subsequently, housing markets needed to react to rapidly increasing demand in various areas, from studio apartments for short-term stays to family dwellings and gentrification trends. While the demand-driven aspects can be regarded as rather restricted during the first years of urban growth, a diversification process of housing typologies could be observed during the following peri- od due to a more globalized and advanced real estate industry (Bardhan, Kroll 2007).

Various factors dictate the housing types preferred by migrant groups in emerging cities. This can be observed in cases of migrants from rural or urban places as well as migrants from various socioeconomic and sociocultural backgrounds (Salama 2015). While a low-income background generally restricts the choice of housing and thus dictates certain lifestyles, high income groups have a bigger variety of residences to choose from (Narwold, Sandy 2010). This fact is displayed by the increasing diversity of upper real estate markets, while affordable housing schemes often follow more repetitive models, mainly dictated by land prices and construction costs (Gurran et al. 2007: 44). These parameters, however, are dependent on general infrastructural networks and development policies. Subsequently, various new housing development patterns can be identified in emerging cities, particularly in the Global South, where they face a continuous updating process rooted in new dynamics, including 
rising land and rental prices, new demographic characteristics and the economic realities resulting from migration (Aerni 2016).

In recent years, lifestyle research has played an increasingly important role in understanding housing patterns and thus urban development dynamics. Primarily, the introduction of lifestyle groups follows the need of economists to predict future demand patterns within complex and advanced markets. The theories of "Sinus-Milieus" (Sinus Institute 2016) are thus often used in real estate studies to point out market potentials as well as deficits in particular areas (Gröger et al. 2011). In light of the notion that lifestyles lead to certain housing choices, new housing developments can be studied as a reflection of these new lifestyles. This paper investigates key housing trends in four emerging cities in the Gulf region and their manifestations of lifestyle trends. Lifestyles are seen as a product of individual preferences but within the context of local spatial and economic realities. Thus, the investigation of lifestyles and their relationship with housing typologies places emphasis on understanding current developments rather than following the economists' approach to quantify market potentials and deficits.

\section{Lifestyle theories and housing}

Contemporary literature emphasizes that housing is more than the pure need for shelter. The home environment can be seen as both a form of self-expression and an important spatial factor defining human perceptions (Marcus 1997). Where and how a human was raised will always affect future choices and his or her acceptance of certain residences (Freeman 1998: 330). Additionally, the age, income level and household size will also impact the preference of certain housing types. To study the relationship between housing and lifestyles, the basic needs must first be identified. While the need for shelter can be seen as the lowest level of needs based on the simple premise of human survival, the social needs to establish a sense of belonging are followed by the individual needs of self-expression (Newmark, Thompson 1977). In principle, lifestyle theories are based on a complex framework that acknowledges the reality of human beings as being driven by dynamic interactive factors rather than static personal and situational factors (Walters 2006: 3).

In 1977, Pierre Bourdieu introduced the concept of habitus as the result of both the hexis (a more or less stable disposition of knowledge or character) and more complex mental and subjective schemes of perception (Bourdieu 1977). Habitus refers to past experiences resulting in different skills, dispositions and habits, which lead to certain socio-behavioural practices. According to Bourdieu, each social class shares a certain general habitus due to similar environments and thus experiences. This habitus has a direct impact on each individual leading to dynamics between given structures, which have developed over generations, and new individual perceptions introducing certain restructuring processes (Bourdieu 1987). The habitus can thus be identified as a holistic approach towards understanding the origin of lifestyles and the result of a long-term historic evolution, which is continuously changing. According to Bourdieu, individuals need their habitus to find new solutions based on their intuition, which in his view is directly linked to societal norms. The resulting lifestyles have significant impact on how social structures and spatial development patterns evolve because they influence the ideas that define a good society (Benedikter 2012).

In 1970, the British anthropologist Mary Douglas introduced her "group and grid" model in her book "Natural Symbols" (Douglas 1970). According to her definition, a group implies a general boundary around a community, which is based on choice, and a grid includes the outer forces and regulations. Douglas distinguishes between four main group-grid types: the "isolate", the "positional", the "individualist", and the "enclave". While the "isolate" only includes social groups that have been isolated by the system, such as prisoners, and therefore hardly has any impact on developments, the "individualist" is mainly concerned with private benefits and is therefore a product of an increasingly commercial society (Douglas 2006: 6). Therefore, social status and its expression can play an important role in housing dynamics (Chapman 1955). The "positional" is rooted in a distinct group following a clear grid-given structure and thus often supports tradition and order (Douglas 2006: 4). Finally, the "enclave" includes all groups that refuse to participate in any given framework and follow own structures (Douglas 2006: 5). These four fundamental types offer an enhanced understanding of general lifestyle dynamics. The diversity of lifestyles is thus highly dependent on the general social structure.

In addition to the holistic approach of understanding lifestyles as the result of the habitus as defined by Bourdieu and following the clear positions within Douglas's "group and grid" model, other scholars have introduced pragmatic models on how to distinguish certain life modes that shape lifestyle trends today. In his book "State, Culture, and Life-Modes: Foundations of Life Mode Analysis" (2003), Thomas Hojrup introduced three pragmatic life modes: self-employed life mode, wage earner life mode, and career oriented 
life mode (Hojrup 2003). The preceding classification shows that house needs and preferences usually vary based on the income level, work sector, and work style of an individual (Salama 2011: 10). While life modes can be distinguished according to the varying ways in which people work, other factors such as the demographic increase and decrease of families and the associated life modes have been researched by scholars to investigate the dynamics of housing markets (Graham, Sabater 2015).

Coupled with how people work and their family status, the role of leisure- and consumption-oriented life modes can be identified as the third determining factor for housing choice. While some social groups are significantly restricted in their spending, others consciously choose to save their earnings or at least a portion of them. Other groups alternatively opt for a predominantly if not solely consumer-driven lifestyle, as analyzed and described by Thorsten Veblen in the late $19^{\text {th }}$ century (Veblen [1899] 2009). Still, among the three types of social groups, work and family status as well as consumption patterns determine housing preferences within the constraints of supply and demand (Beamish et al. 2001).

Concluding the preceding theories as they relate to housing preferences and choices, lifestyles have always been drivers for housing developments, while the existing housing conditions have a reciprocal impact on lifestyles. Lifestyles are a product of individual and collective processes within societies and, therefore, their characteristics are highly complex. A new frame- work is thus developed (Fig. 1) to integrate the various parameters that shape the lifestyles of different social groups. According to Bourdieu's theory, society is the product of a historic process and the organization of a society is directly linked to past experiences. This is manifested in the individual's habitus, which is rooted in cultural customs as well as basic survival needs and their social status. This abstract conception of the foundation of lifestyles in addition to the understanding of the present group-grid structure of a society provides an overview of basic social groups and their roles. The theoretical understanding of how societies are structured needs to be incorporated into an understanding of predominant life modes as drivers of new restructuring processes. These life modes can be defined by being family-related, work-based, or leisure-oriented.

\section{Methodology and procedures}

Emerging multicultural societies are rooted in extensive international migration and are particularly important cases whereby new housing dynamics and lifestyle trends can be observed. Hence, this paper addresses the fastest growing Gulf cities including Dubai, Abu Dhabi, Doha and Manama as its case studies. According to previous studies (Salama, Wiedmann 2013: 25), all four Gulf cities share key characteristics regarding migration patterns, economic restructuring processes and spatial development. Subsequently, key trends in the dynamics between housing typologies and emerging lifestyle groups can be observed in the four cities. This paper's methodological approach

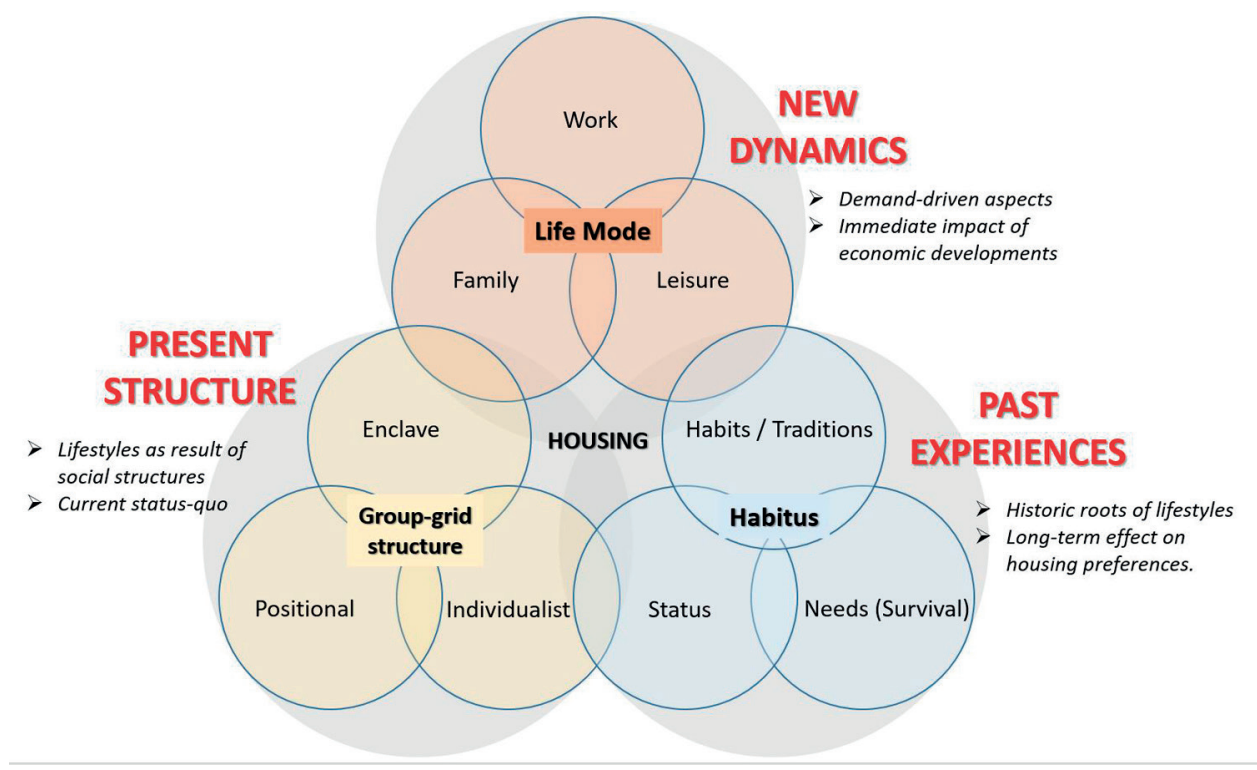

Fig. 1. A transdisciplinary framework for understanding housing as a reflection of historic processes, social structures and dominant life modes. Source: Authors. 
is thus based on a regional rather than local scale to avoid the limitations of utilizing only one case study.

Since the primary objective of this paper is to introduce a new understanding of the general dynamics between group lifestyles and housing trends, the methodological approach is centred on analysing social structures by following a new framework for characterizing particular group lifestyles and on evaluating data in order to introduce the main housing typologies.

The demographic structures were analysed by examining recent official reports and data. The main aim is to identify the various countries of origin, the gender distribution and the age groups in the context of employment and income. Based on the new framework four important lifestyle tendencies can be identified.

The housing typology studies include a strategic collection of data of recently built housing units in the four Gulf cities in accordance with a review of official real estate reports. In total, 240 samples were collected by conducting a web survey of real estate development companies, which was coupled by a series of contacts and visits to architectural firms. While 120 of the cases are apartment units in various locations, the remaining 50 per cent are villas and town houses. The strategic selection of all samples is based on a general real estate review of all four cities based on official reports and media articles. Based on this review, six typical development trends could be identified and analysed.

Representative ground floor plans are explained on the basis of a statistical evaluation of all samples for each housing type by investigating key characteristics. These six ground floor plans are evaluated based on a set of certain research questions (Table 1):

- Entrance: The entrance and access to the unit is an important indicator, if a dwelling is utilized for socializing and hosting guests. Thus, the sizes are measured and layouts are investigated in each case study. Cultural particularities can be identified in the case of separate entrances.

- Private and public spaces: The general ratio between private spaces (bedrooms) and shared spaces is important for identifying the general tendency of housing to be designed either for hosting families and their guests or to be flexible for shared living, particularly in the case of migrant employees. In addition to sizes, the layouts were evaluated in each case.

- Kitchen type: The third evaluation step is focused on how kitchens have been integrated. An integration of kitchens in open living areas is often an indication of a certain lifestyle focusing on working outside the home and dining out.
- Exposure to daylight: Another important aspect is the general exposure to daylight, which is another indicator of whether housing is built and used merely as necessary shelter or as important spaces where a large share of life is taking place.

- Neighbourhood: In addition to the layout and sizes of each housing type, the typical neighbourhoods were investigated to identify common trends in integrated services and leisure opportunities.

- Architectural style: Last but not least, architectural styles were investigated and compared by distinguishing the main interior and exterior design languages (oriental, Mediterranean, modern as well as eclectic).

Conclusions are established to provide an overview of the key challenges and current situation of housing supply and the emerging lifestyle groups in an increasingly multicultural society.

Demographics and lifestyle trends in gulf cities Before major lifestyle trends can be identified and characterized, the general demographics need to be analysed. Rapid migration has led to a particular demographic structure and a consequent predominance of migrant groups in all four cities. From 2005 to 2015, more than 3 million migrants moved to all four cities. A large share of migrants has been staying a limited number of years due to short-term contracts, which has led to high annual emigration in parallel to the increasing immigration. South Asians, particularly from the Indian Subcontinent, constitute the biggest share of all migrants (around 80 per cent). Due to the expanding construction industries, the majority of this segment of the population are male labourers (De Bel-Air 2014, 2015a, 2015b). These labourers are housed in particular accommodations provided by employers, located either in deteriorating downtown districts or in industrial areas. In all four cities, labourers are provided with accommodation by their employers and they are not permitted to move with their families (Gardner et al. 2013). Based on the evaluated statistics of all four cities, these labourers make up at least 40 per cent of the urban population (Abu Dhabi Statistics Centre 2016; Bahrain Information \& eGovernment Authority 2014; Dubai Statistics Center 2015; MDPS 2016).

The next lowest income group can be described as low to medium income, mainly from the Indian Subcontinent, the Philippines and the MENA region. This group is engaged in service sectors, such as construction, trade and tourism, and includes many migrants and their families who have settled in the four Gulf cities during previous decades. Specifically, a large share of this group is from countries like India, 
Pakistan, Egypt, Iran and Sudan. Although medium income groups with a minimum monthly wage (around $\$ 2,700$ in Qatar and the UAE) are usually permitted to move with their families, a large share has moved as singles due to short-term contracts and due to being young professionals (De Bel-Air 2014, 2015a, 2015b). This migrant group accounts for 30 to 40 per cent of the urban population in each city.

The remaining share of the urban population is split into two groups. First, the local population constitutes only around 10 to 20 per cent of the urban population in in all four cities, and second, medium to high income expats add up around 10 per cent of the population. The medium to high income migrants are the most diverse group as they include migrants from Western and Middle Eastern countries.

The local population is the most insular across all four cities. All statistics show a very low level of active participation of most locals in the private sector (De Bel-Air 2014, 2015a, 2015b). The majority is engaged in public sector occupations in addition to their decisive roles as landlords and investors. Most locals left cities and reside in the periphery or in satellite settlements and their homogeneous neighbourhoods essentially belong to a separate housing market, guided by the land distribution of governments and rigid development policies. In summary, all four cities have a very dis- tinctive demographic structure in spite of their different sizes, historic backgrounds and differing political leadership (Fig. 2). All four cities share a very similar structure as concerns the backgrounds of migrants, which include their origin, income distribution and age groups. Thus, major lifestyle trends can be identified, which apply to all four cities.

Based on income levels, cultural preferences and existing urban conditions in all four Gulf cities, four main lifestyle trends can be distinguished as analytically discussed hereunder (Fig. 3):

1) Work-focused: In much of the service sector, young professionals have moved to Gulf cities for earning and saving money on a temporary basis. In spite of their limited income and their objective to save their earnings, they usually adhere to basic principles of order and traditional values. This is rooted in their uncertain employment situation coupled with their Asian and Middle Eastern cultural backgrounds. Leisure time is rather reduced and is usually spent in public spaces and accessible shopping malls, where the main activity is focused on meeting friends from a similar cultural background.

2) Family-oriented: This family-oriented lifestyle group includes migrants who have settled in

\begin{tabular}{|c|c|c|c|c|}
\hline $\begin{array}{l}\text { City } \\
\text { (metro) }\end{array}$ & Doha & Manama & Abu Dhabi & Dubai \\
\hline Population & $1,351,000$ & 411,000 & $1,720,000$ & $2,663,000$ \\
\hline Origin & $\begin{array}{c}\text { Middle Western } \\
\text { Eastern }\end{array}$ & 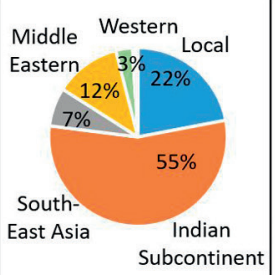 & 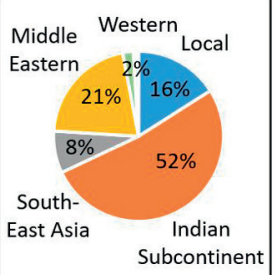 & $\begin{array}{l}\text { Middle Western } \\
\text { Eastern }\end{array}$ \\
\hline $\begin{array}{l}\text { Age } \\
\text { structure }\end{array}$ & $25-54$ & $25-54$ & $\begin{array}{r}62 \% \\
25-54\end{array}$ & $28 \%$ \\
\hline Gender & Female & Female & Female & Female \\
\hline
\end{tabular}

Fig. 2. An overview of the demographic structure in all four cities

Source: Authors referring to data from the Gulf Labour Markets and Migration Programme 2016 and the author De Bel-Air 2014, 2015a and 2015b in addition to official data from: Abu Dhabi Statistics Centre 2016; Bahrain Information \& eGovernment Authority 2014; Dubai Statistics Center 2015; MDPS 2015 and 2016. 


\begin{tabular}{|c|c|c|c|}
\hline Work-focused & Family-oriented & Mobile International & Local Traditional \\
\hline individualist & leisure & $\begin{array}{r}\text { positional } \\
\text { in }\end{array}$ & $\begin{array}{l}\text { positional } \\
\text { individu }\end{array}$ \\
\hline $\begin{array}{l}\text { - } 30 \text { to } 40 \% \text { of the urban population } \\
\text { - Low to medium income } \\
\text { - } \text { mainly male; average age: } 27 \\
\text { - origin: mainly South Asia. }\end{array}$ & $\begin{array}{l}\text { - } 30 \text { to } 40 \% \text { of the urban population } \\
\text { - Low to medium income } \\
\text { - Average age: } 32 \\
\text { - origin: MENA \& South Asia }\end{array}$ & $\begin{array}{l}\text { - } 10 \text { to } 15 \% \text { of the urban population } \\
\text { - Medium to high income } \\
\text { - average age: } 37 \\
\text { - origin: mainly Western \& MENA }\end{array}$ & $\begin{array}{l}\text { - } 10 \text { to } 15 \% \text { of the urban population } \\
\text { - Medium to high income } \\
\text { - average age: } 34 \\
\text { - origin: GCC }\end{array}$ \\
\hline $\begin{array}{l}\text { Key lifestyle characteristics: } \\
\text { - Lifestyle dominated by work; no } \\
\text { families and reduced leisure } \\
\text { time. } \\
\text { Habitus and past experiences } \\
\text { are mainly rooted in survival } \\
\text { needs. } \\
\text { Clear collective position as } \\
\text { workforce with short-term } \\
\text { contracts and engagements. }\end{array}$ & $\begin{array}{l}\text { Key lifestyle characteristics: } \\
\text { - Family-orientation and balanced } \\
\text { work and leisure focus. } \\
\text { - Habitus and past experiences are } \\
\text { mainly rooted in habits / traditions } \\
\text { and basic needs for survival. } \\
\text { - Clear collective position as } \\
\text { workforce and focused on a } \\
\text { possible long-term settlement. }\end{array}$ & $\begin{array}{l}\text { Key lifestyle characteristics: } \\
-\quad \text { Work and leisure focus. } \\
\text { - Habitus and past experiences } \\
\text { are mainly rooted in status- } \\
\text { driven aspects, rather than } \\
\text { traditions and survival. } \\
\text { Individualists focusing on their } \\
\text { professional career; rather } \\
\text { detached from the majority of } \\
\text { the urban population. }\end{array}$ & $\begin{array}{l}\text { Key lifestyle characteristics: } \\
\text { - } \quad \text { Family and leisure focus. } \\
\text { - Habitus and past experiences } \\
\text { are mainly rooted in traditions } \\
\text { and status; life adjustments } \\
\text { based on survival needs are no } \\
\text { recent experiences. } \\
\text { Enclave characteristics due to } \\
\text { their role as minority; detached } \\
\text { from migrant communities. }\end{array}$ \\
\hline $\begin{array}{l}\text { Housing typologies: } \\
\text { - Apartment buildings in dense } \\
\text { urban areas or in far distances. }\end{array}$ & $\begin{array}{l}\text { Housing typologies: } \\
\text { - } \quad \text { Affordable compounds and } \\
\text { apartment buildings. }\end{array}$ & $\begin{array}{l}\text { Housing typologies: } \\
\text { - Apartments in mega projects } \\
\text { and villas in compounds. }\end{array}$ & $\begin{array}{l}\text { Housing typologies: } \\
\text { - Villas in traditional local } \\
\text { neighbourhoods. }\end{array}$ \\
\hline
\end{tabular}

Fig. 3. The main characteristics of the four lifestyle groups Source: Authors.

Gulf cities for decades and newly arriving migrant families with sufficient income whose objective is to settle for a longer period of time. Due to the required minimum income, most of these migrants meet a minimum educational background and are usually from Asia or the Middle East. In contrast to the work-focused migrants, this group often has the opportunity and objective to settle long-term in Gulf cities. Their lifestyle is usually centred on family living where car ownership plays an important role in enabling various family activities.

3) Mobile internationals: The third migrant group consists of high income expats who move with or without families to Gulf cities and who usually have plans to stay for a limited period of time. This group is mainly attracted by high salaries and the high level of international mobility. The Gulf experience is perceived as an opportunity for professional experience. Thus, mobile internationals are diverse in age as well as country of origin, most of which being Arab or Western. Their housing choices are less driven by private budget considerations and more by their demand for a certain living standard and an expression of their professional status. While this group follows a clear "individualist" approach, it finds itself contained in a newly built gated environment.

4) Local traditional: The last lifestyle group, which significantly differs from the three previous groups, constitutes the traditional local population. As a result of fast growth and rapid migration, the local population has found itself in a separate world, detached from the rules and economic forces that migrants are facing. In some cases, as in Bahrain, the local population is relatively complex and diverse, particularly on the basis of income levels. Despite the fact that not all local inhabitants have a high income, they all share the objective of preserving their local traditions and customs, as they have become a social minority. The land distribution for local housing developments enables this group to live in an almost detached space and thus "enclave" trends can be detected. Most leisure time is spent in private and spacious villas where the different generations meet and interact. Local neighbourhood mosques also play a significant role within these communities.

\section{Housing dynamics and typologies in Gulf cities}

Extensive migration and the resulting multicultural society have together led to a quick transformation of 
local housing markets in all four Gulf cities. The need to accommodate a diverse workforce as well as the rising pressure of investments on freehold properties have both resulted in a clearly defined real estate sector. On the one hand, mass housing has been needed to accommodate low to medium income migrants, while on the other hand, exclusive mega projects have become the actual drivers of urban growth. In parallel, the housing market for the local populations has continued on the basis of land distribution in secluded suburban areas. Last but not least, labour accommodations have been built in order to shelter the large and frequently exchanging labourers from South Asia.

In general, three main urban development trends can be identified: (1) the continuous expansion of suburban areas, (2) the development of densely built areas in proximity to downtown and industrial areas and (3) the launch of mega projects, particularly along waterfronts. These general development patterns have led to six distinctive housing typologies, which can be analysed in the context of the four previously identified lifestyle groups (Fig. 4; Table 1):

\section{Apartments in densely built mixed-use areas}

In proximity to the historic centres and in transition areas along urban fringes, densely urban areas have emerged in recent years. In accordance with local regulations, the main housing typology has been apartment towers with an average height of eleven floors in downtown areas and five to seven floors in transition areas. The most common type is the 2- and 3-bedroom apartment. According to the case studies, an average of

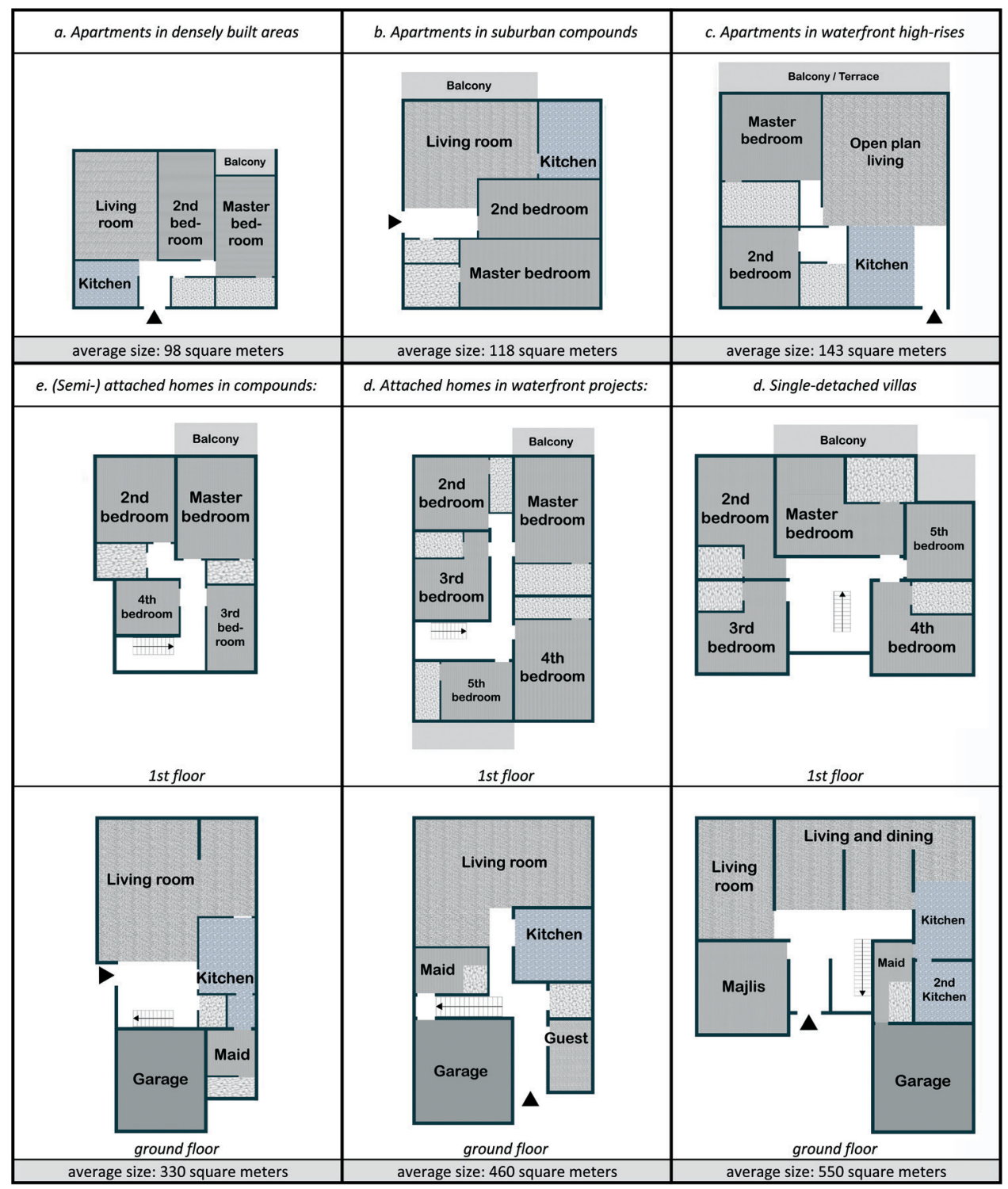

Fig. 4. The six most common housing typologies' in Gulf cities Source: Authors. 
Table 1. The key characteristics of the six common housing typologies in Gulf cities

\begin{tabular}{|c|c|c|c|c|c|c|}
\hline & $\begin{array}{l}\text { Suburban } \\
\text { Apartments } \\
\text { (villas \& } \\
\text { blocks) }\end{array}$ & $\begin{array}{l}\text { Downtown } \\
\text { Apartments } \\
\text { (blocks \& } \\
\text { high-rise) }\end{array}$ & $\begin{array}{l}\text { Waterfront } \\
\text { Apartments } \\
\text { (high-rise) }\end{array}$ & $\begin{array}{c}\text { Compound } \\
\text { houses } \\
\text { (attached \& } \\
\text { semi-attached) }\end{array}$ & $\begin{array}{c}\text { Waterfront } \\
\text { houses } \\
\text { (attached \& } \\
\text { semi-attached) }\end{array}$ & $\begin{array}{l}\text { Suburban Villa } \\
\text { (detached) }\end{array}$ \\
\hline $\begin{array}{c}\text { Entrance \& } \\
\text { access }\end{array}$ & $\begin{array}{c}\text { Entrance } \\
\text { usually leads to } \\
\text { a central lobby } \\
\text { (average size: } \\
5.9 \text { sq m). }\end{array}$ & $\begin{array}{l}\text { Entrance } \\
\text { usually leads } \\
\text { directly into a } \\
\text { corridor } \\
\text { (4.8 sq m). }\end{array}$ & $\begin{array}{c}\text { Entrance } \\
\text { usually leads } \\
\text { to a large open } \\
\text { plan living area } \\
\text { (6.1 sq m). }\end{array}$ & $\begin{array}{l}\text { Entrance } \\
\text { usually leads } \\
\text { to a lobby and } \\
\text { semi-open } \\
\text { living area } \\
\text { (20 sq m). }\end{array}$ & $\begin{array}{l}\text { Entrance leads } \\
\text { to central } \\
\text { corridor } \\
\text { connecting all } \\
\text { rooms } \\
\text { (15 sq m). }\end{array}$ & $\begin{array}{l}\text { Entrance leads } \\
\text { to a big lobby } \\
\text { and stairways } \\
\text { (35 sq } \mathrm{m}) .\end{array}$ \\
\hline $\begin{array}{c}\text { Private : } \\
\text { public space }\end{array}$ & $66 \%: 34 \%$ & $71 \%: 29 \%$ & $61 \%: 39 \%$ & $51 \%$ : 49\% & $57 \%$ : 43\% & $44 \%: 56 \%$ \\
\hline $\begin{array}{l}\text { Kitchen: Type } \\
\text { \& location }\end{array}$ & $\begin{array}{c}\text { Separate } \\
\text { kitchens and } \\
\text { open kitchens } \\
\text { are both } \\
\text { frequent (55\%: } \\
45 \%) .\end{array}$ & $\begin{array}{c}\text { Separate } \\
\text { kitchens in } \\
\text { most cases } \\
(62 \%) .\end{array}$ & $\begin{array}{c}\text { Separate } \\
\text { kitchens and } \\
\text { open kitchens } \\
\text { are both } \\
\text { frequent (56\%: } \\
44 \%) .\end{array}$ & $\begin{array}{l}\text { In most cases } \\
\text { kitchens are } \\
\text { separate (90\%). }\end{array}$ & $\begin{array}{c}\text { A majority } \\
\text { of separate } \\
\text { kitchens }(64 \%) \\
\text { and a big share } \\
\text { of open plan } \\
\text { living. }\end{array}$ & $\begin{array}{l}\text { In all cases, } \\
\text { kitchens are } \\
\text { separate. Many } \\
\text { villas integrate } \\
\text { a second open } \\
\text { breakfast } \\
\text { kitchen. }\end{array}$ \\
\hline $\begin{array}{l}\text { Daylight \& } \\
\text { orientation }\end{array}$ & $\begin{array}{l}\text { Sufficient. Most } \\
\text { sitting areas } \\
\text { are oriented } \\
\text { towards the } \\
\text { north (68\%). }\end{array}$ & $\begin{array}{l}\text { Limited. The } \\
\text { orientation of } \\
\text { sitting areas } \\
\text { is directed } \\
\text { towards the } \\
\text { north and } \\
\text { south equally } \\
\text { (51\%:49\%). }\end{array}$ & $\begin{array}{l}\text { Good. The } \\
\text { orientation of } \\
\text { sitting areas } \\
\text { is directed } \\
\text { towards the } \\
\text { north and } \\
\text { south equally } \\
\text { (53\% : 47\%). }\end{array}$ & $\begin{array}{l}\text { Sufficient. Most } \\
\text { sitting areas } \\
\text { are oriented } \\
\text { towards the } \\
\text { west (89\%). }\end{array}$ & $\begin{array}{l}\text { Sufficient. The } \\
\text { direction of the } \\
\text { sitting areas } \\
\text { depends on the } \\
\text { coast. }\end{array}$ & $\begin{array}{l}\text { Good. Due to } \\
\text { the absence } \\
\text { of attached } \\
\text { buildings, all } \\
\text { rooms have } \\
\text { access to } \\
\text { daylight. }\end{array}$ \\
\hline $\begin{array}{l}\text { Neighbour- } \\
\text { hood }\end{array}$ & $\begin{array}{l}\text { Suburban } \\
\text { surroundings. } \\
\text { Low } \\
\text { integration of } \\
\text { services. }\end{array}$ & $\begin{array}{l}\text { Densely } \\
\text { built and } \\
\text { mixed-use } \\
\text { environment. }\end{array}$ & $\begin{array}{l}\text { Integrated } \\
\text { leisure and } \\
\text { commercial } \\
\text { services in most } \\
\text { cases }(99 \%) .\end{array}$ & $\begin{array}{l}\text { Low integration } \\
\text { of services. } \\
\text { Some shared } \\
\text { leisure facilities. }\end{array}$ & $\begin{array}{l}\text { Some shared } \\
\text { leisure facilities. } \\
\text { Proximity } \\
\text { to public } \\
\text { leisure and } \\
\text { commercial } \\
\text { areas. }\end{array}$ & $\begin{array}{l}\text { Low integration } \\
\text { of services } \\
\text { apart from } \\
\text { schools and } \\
\text { mosques. }\end{array}$ \\
\hline $\begin{array}{l}\text { Architectural } \\
\text { design }\end{array}$ & $\begin{array}{c}\text { Modern } \\
\text { design, } \\
\text { Western (51\%) } \\
\text { and oriental } \\
\text { style }(49 \%), \\
\text { cladding and } \\
\text { cement. }\end{array}$ & $\begin{array}{c}\text { Functional } \\
\text { modern } \\
\text { design (95\%); } \\
\text { prefabricated } \\
\text { cement (63\%). }\end{array}$ & $\begin{array}{l}\text { Modern design } \\
(75 \%) ; \text { steel \& } \\
\text { glass }(51 \%) \text { and } \\
\text { cladding (49\%). }\end{array}$ & $\begin{array}{l}\text { Widespread } \\
\text { traditional } \\
\text { ornaments } \\
(30 \%) \text { and } \\
\text { modern design. }\end{array}$ & $\begin{array}{l}\text { Mainly modern } \\
\text { design and } \\
\text { widespread } \\
\text { oriental } \\
\text { ornaments. }\end{array}$ & $\begin{array}{c}\text { Mainly } \\
\text { traditional } \\
\text { ornaments and } \\
\text { a certain share } \\
\text { of eclectic } \\
\text { design styles. }\end{array}$ \\
\hline
\end{tabular}

Source: Authors.

2.3 bedrooms and average size of 95 square meters can be found. The majority of these apartments accommodate the shared living of migrants with work-focused lifestyles. The remaining share is inhabited by migrant families that are looking for rental rates more affordable than those in accessible suburban areas. The apartments follow regional standards and are not specifically designed for shared living. While private bedrooms cover most of the evaluated ground floor plans (71 per cent), the big size of bedrooms and the consequently higher rental rates have led to shared rooms and a lack of privacy. In most cases (62 per cent), kitchens are separate. The sitting areas are usually facing the north or the south and no clear preference can be detected. In general, daylight is often limited due to the densely built surroundings and short distances between buildings. The neighbourhood surroundings often include basic commercial services. Social infrastructure, such as schools and public spaces, are however limited due to the absence of a need to accommodate a large number of families. The architectural style is dominated by the functional appearance of prefabricated cement elements and lacks general attractiveness. The high frequency of changing tenants has led to a visible instant neighbourhood environment hardly reflecting the need for homes but instead serving as pure shelter.

\section{Apartments in suburban compounds}

While urban areas along the fringes of historic city cores have been witnessing rapid growth due to vertical 
typologies, the suburban sprawl has continued. In addition to villas and town houses, an increasing number of apartment buildings and blocks have been integrated into compound developments to accommodate low to medium income migrants. Due to local regulations, this housing typology usually reaches an average height of three to four floors and the typical apartment reaches a size of up to 120 square meters due to the prevalence of 3-bedroom apartments (2.45 on average) among all 40 samples. The apartments were designed following regional standards with particular consideration for family-oriented lifestyles. The entrance usually leads to a small lobby and is slightly bigger in shared living spaces than in downtown apartments (34 per cent of the total area). Both separate and open kitchens are found equally. While certain amenities, such as swimming pools and gyms, are often included within the compound precincts, general commercial services and social infrastructure are usually less integrated, which ultimately leads to higher car dependency. In the case of the 40 evaluated compounds, the architectural design either follows a modern functional design language or oriental ornamentation. The rental prices highly vary depending on the location.

\section{Apartments in exclusive waterfront high-rises}

Since the beginning of the construction boom, coastal areas have been witnessing rapid development including their extension via further land reclamation. Due to high land prices and generally well accessible locations, high-rise buildings with up to 101 floors have been built. In the case of the investigated samples, the ground floor plans reach an average size of 140 square meters. The average number of bedrooms is 2.2 and there is a diversity of apartments from studio apartments to four bedrooms. In most cases, the entrance directly leads to a large spacious open plan living area, which covers an average of almost 40 per cent of the entire ground floor plan. This clearly representative space accommodates the needs of a mobile international lifestyle. As in the case of suburban apartments, both separate and open kitchens can be found. Access to daylight is plentiful and the orientation of sitting areas is dependent on the view. Spacious terraces and balconies are often integrated to underline the exclusiveness of this typology, which is further expressed by many in-house services and leisure activities. The architectural design of most high-rise buildings is essentially influenced by Western design, expressed through modernist steel and glass architecture. While the coastal areas integrate various amenities and services due to a high density of hotels, social infrastructure is limited due to high land prices. Furthermore, the high rental rates have led to high vacancy rates and widespread shared living.

\section{Attached and semi-attached homes in compounds}

In all four cities, compound regulations permit the development of more densely built plots by constructing attached or semi-attached homes. In many cases these homes, are still recognized as individual houses. The typical compound home has an average size of 330 square meters and two floors. The entrance leads to a medium sized lobby or semi open-plan living area. The proportion of private bedrooms to shared living areas is usually balanced due to the general layout of bedrooms being located on the first floor. This typology mainly accommodates family-oriented groups with medium and high income. The design follows regional standards and conservative layouts. In most cases $(90$ per cent), kitchens are separate and, in the majority of cases, small rooms for maids have been integrated. Due to the size of these homes, living areas are usually not separated and thus there is usually no traditional majlis for male visitors in proximity to entrances. These suburban neighbourhoods are usually served by shopping malls and small district centres. Yet, all residents rely on the car as main mode of transportation. In most cases, the precincts of the compound integrate shared leisure areas, such as a gym, pool and small playgrounds depending on the size of the compound.

\section{Attached and semi-attached homes in mega projects}

In addition to attached homes in compounds, such typology is also prevalent across mega projects, particularly those on reclaimed or coastal land. With an average size of around 460 square meters, these homes are significantly bigger than the usual compound homes. Due to their location in gated mega projects, they usually form linear and open developments unlike the compactness found in compounds. These homes accommodate high-income family-oriented lifestyles of migrants, particularly from the MENA region including other Gulf states, as well as local communities that are open for international housing standards. The entrances lead to a central corridor or lobby and the share of areas occupied by private bedrooms is slightly lower (57 per cent) due to big open representative areas and large balconies. The share of open-plan-living spaces (almost 40 per cent) is significantly higher than that found among typical compound homes, which is a sign of the tendency towards a modern and contemporary layout. The architectural design is mainly modern, but both oriental and Mediterranean design elements can be found. The integration of commercial services, such as small malls, permits the proximity of the homes and neighbourhoods to various leisure areas. In the case of waterfront projects, many homes have 
access to a small private beach. As in the case of exclusive tower projects, the supply of social infrastructure is limited due to high land prices and few guidelines forcing developers to integrate sufficient services.

\section{Single-detached villas}

Since the rise of oil production in the Gulf cities under study, the native population has moved towards suburban districts. The resulting homogeneous neighbourhoods mainly consist of single-detached villas. The average living area within contemporary single-detached homes reaches between 500 to 600 square meters, which is the biggest size out of all typologies. The housing design follows the requirements of traditional homes in Gulf states and the objective to accommodate large families. In addition to a main representative entrance leading to a large central lobby with stairways, a servant entrance is usually integrated to permit separated movements. Next to the main entrance, a private sitting area, known as majlis, is often integrated to allow the separation of male and female guests in accordance with local customs. The family living room is placed next to the dining room, which usually incorporates a small open kitchen, while the kitchen for daily cooking is located outside of the main living areas next to the servants' rooms and utility rooms. The first floor is most commonly occupied by mainly bedrooms and their bathrooms. In some cases, a living room is integrated to permit intergenerational living under one roof. The villas usually have sufficient access to daylight despite their large ground floor area. Skylights in the stairways area are often used to improve the natural lightning in central areas. The villas are usually built in the centre of standardized plots, which are surrounded by a high wall to protect the families' privacy. The neighbourhoods integrate basic social infrastructure, but hardly any commercial services. The architectural design varies between various design languages from Mediterranean to modern simplistic. Among the most common design elements are oriental ornaments.

\section{Conclusions}

Due to the frequent exchange of migrants, a particular social structure, often referred to as airport society, has emerged in the Gulf cities of Dubai, Abu Dhabi, Doha and Manama. Today, it is expected that low-income migrants, particularly labourers, will be less needed in the future and that the local populations will eventually play a more decisive role across the private sectors. Housing developments, however, mainly reflect the need for a quick supply of sufficient housing on the one side and the speculation-driven trade with freehold properties on the other. The resulting urban landscapes in all four Gulf cities can therefore be described as agglomerations of highly dense downtown and industrial areas surrounded by mega projects and urban sprawl (Fig. 5).

The significantly different lifestyle groups express a strong segregation of income as well as cultural backgrounds. Accordingly, the differing housing typologies of these lifestyle groups and their locations have furthermore led to a high spatial segregation. The largest proportion of migrants currently perceives Gulf cities as a temporary opportunity to earn money and professional experience. The frequent exchange of this group
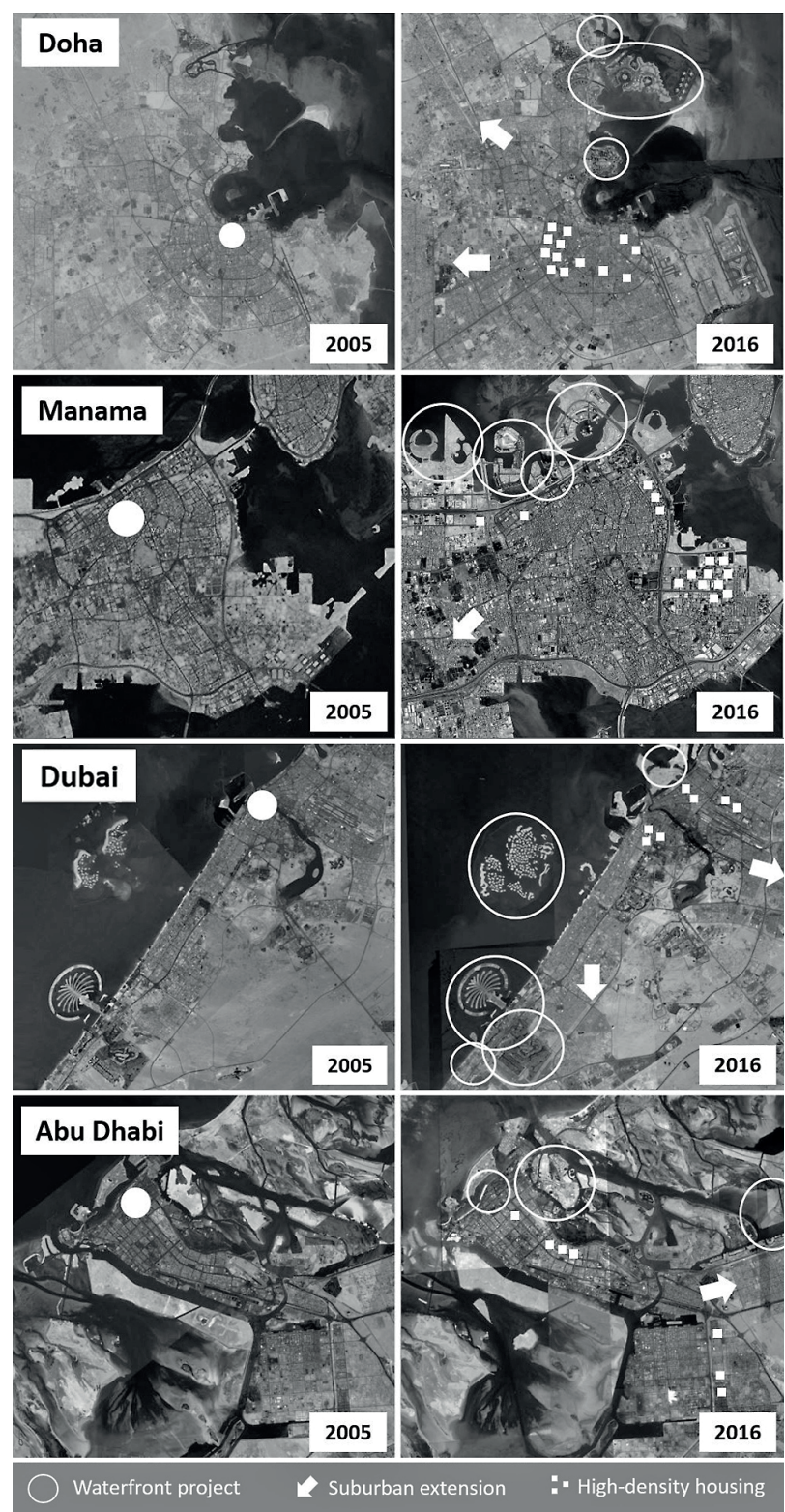

Fig. 5. The spatial distribution of suburban extensions, mega projects along waterfronts and high-density housing in all four cities

Source: Authors. 
has led to a housing market in which most properties are built to supply basic needs, rather than accommodate cultural particularities. This shelter-approach has led to densely populated areas that now face the major threat to turn into highly problematic districts with increasing crime rates and shrinking liveability.

The biggest affordable housing crisis can be found in the case of migrant medium-income families that have decided to settle long-term. The complex requirements regarding safe surroundings, schools and mobility have made many downtown areas unsuitable for families. The move to suburbs has therefore been the logical consequence where more and more apartment buildings have been built within compounds in far distances from urban centres to accommodate this large migrant group.

While the two biggest lifestyle groups are struggling to find appropriate and affordable housing, the higher income groups have the option to decide between a growing variety of exclusive projects from waterfront high-rise apartment buildings to villas along golf courses. However, this group is shrinking and the vacancy rates of the most exclusive housing projects are thus high. Recent real estate investments have focused on this upper market due to the biggest profit shares. This has led to a high discrepancy between overcrowded districts and vacant mega projects.

In all four cities, the local population is facing a growing challenge to maintain the high housing standard, which is still rooted in the first urbanization period and welfare state mechanisms. Despite the common practice to distribute land to locals, the rising construction costs often prevent the development of housing. Thus, many young families are forced to live in their parents' homes. In general, it can be observed that more and more local citizens are forced to move to the free housing market, where adjustments to local customs are visibly lacking.

Contemporary trends in housing reflect a very particular stage of development, in which supply- and speculation-driven dynamics are more dominant than a gradual consolidation and adjustment to the lifestyles of a settled and consolidated multicultural society. In the future, it can be expected that the different lifestyle groups will further diversify and that local housing markets will be tested to accommodate the various needs of migrant and local populations. The long-term settlement of migrant workforce and the beginning engagement of the locals in new economies will become important preconditions for a demand-driven housing market and a clear reflection of a new identity of Gulf cities as integrated multicultural societies rather than as temporary shells and shelters.

\section{Acknowledgements}

This paper was made possible by NPRP grant\# [NPRP 07 - 960 - 5 - 135] from the Qatar National Research Fund (a member of Qatar Foundation). The findings achieved herein are solely the responsibility of the authors.

\section{References}

Aerni, P. 2016. Coping with migration-induced urban growth: addressing the blind spot of UN habitat in, Sustainability 8(8): 800. https://doi.org/10.3390/su8080800

Abu Dhabi Statistics Centre. 2016. Statistical yearbook of Abu Dhabi 2016 - Population [online], [cited 4 September 2016]. Available from Internet: https://www.scad.ae/en/Pages/ ThemesReleases.aspx?ThemeID $=4$

Bahrain Information \& eGovernment Authority. 2014. Bahrain Open Data Portal [online], [cited 4 September 2016]. Available from Internet: http://www.data.gov.bh/ en/DataAnalysis

Bardhan, A.; Kroll, C. A. 2007. Globalization and the real estate industry: issues, implications, opportunities, paper presented at the Sloan Industry Studies Annual Conference, 25-27 April 2007, Cambridge, UK.

Beamish, J. O.; Goss, R. C.; Emmel, J. 2001. Lifestyle Influences on housing preferences, Housing and Society 28(1-2): 1-28. https://doi.org/10.1080/08882746.2001.11430459

Benedikter, R. 2012. Lifestyles, in H. Anheier, M. Juergensmeyer (Eds.). Encyclopedia of global studies. London: Sage Publications, 1076-1080. https://doi.org/10.4135/9781452218557.n335

Bourdieu, P. 1977. Outline of a theory of practice. Cambridge: Cambridge University Press.

https://doi.org/10.1017/CBO9780511812507

Bourdieu, P. 1987. Distinction: a social critique of the judgment of taste. Harvard: Harvard University Press.

Chapman, D. 1955. The home and social status. London: Routeledge and Kegan Paul Ltd.

De Bel-Air, F. 2014. Demography, migration and the labour market in Qatar [online], [cited 4 September 2016]. Available from Internet: http://cadmus.eui.eu/bitstream/ handle/1814/32431/GLMM_ExpNote_08-2014.pdf?sequence $=1 \&$ isAllowed $=\mathrm{y}$

De Bel-Air, F. 2015a. Demography, migration and the labour market in the UAE [online], [cited 4 September 2016]. Available from Internet: http://cadmus.eui.eu/bitstream/ handle/1814/36375/GLMM_ExpNote_07_2015.pdf?sequence $=1 \&$ isAllowed $=y$

De Bel-Air, F. 2015b. Demography, migration and the labour market in Bahrain [online], [cited 4 September 2016]. Available from Internet: http://cadmus.eui.eu/bitstream/ handle/1814/35882/GLMM_ExpNote_06_2015.pdf?sequence $=1 \&$ isAllowed $=\mathrm{y}$

Douglas, M. 1970. Natural symbols: explorations in cosmology. London: Cresset Press.

Douglas, M. 2006. A history of grid and group cultural theory, in Semiotics Institute Online. Semioticon 2006 [online], [cited 4 September 2016]. Available from Internet: http:// semioticon.com/sio/files/douglas-et-al/douglas1.pdf?lbisphpreq $=1 \&$ file $=$ douglas - et - al $/$ douglas $1 . p d f$ 
Dubai Statistics Center. 2015. Population bulletin [online], [cited 4 September 2016]. Available from Internet: https:// www.dsc.gov.ae/Publication/Population\%20Bulletin\%20 Emirate\%20of\%20Dubai\%202015.pdf

Freeman, L. 1998. Interpreting the dynamics of public housing: cultural and rational choice explanations, Housing Policy Debate 9(2): 323-353. https://doi.org/10.1080/10511482.1998.9521297

Gardner, A.; Pessoa, S.; Diop, A.; Al-Ghanim, K.; Trung, K.; Harkness, L. 2013. a portrait of low income migrants in contemporary Qatar, Journal of Arabian Studies 3(1): 1-17. https://doi.org/10.1080/21534764.2013.806076

Graham, E.; Sabater, A. 2015. Population change and housing across the lifecourse: demographic perspectives, methodological challenges and emerging issues. Working Paper Series (64), ESRC Centre for Population Change.

Gröger, M.; Schmid, V.; Bruckner, T. 2011. Lifestyles and their impact on energy-related investment decisions, Low Carbon Economy 2: 107-114. https://doi.org/10.4236/lce.2011.22014

Gulf Labour Markets and Migration (GLMM). 2016. Data \& Documents [online], [cited 4 September 2016]. Available from Internet: http://gulfmigration.eu/glmm-database/

Gurran, N.; Milligan, V.; Baker, D.; Bugg, L. B. 2007. International practice in planning for affordable housing: lessons for Australia. Australian Housing and Urban Research Institute.

Hojrup, T. 2003. State, culture, and life modes: the foundations of life mode analysis. London: Ashgate.

Marcus, C. C. 1997. House as a mirror of self. Berkeley: Conari Press.

MDPS. 2015. Census 2015. Ministry of Development Planning and Statistics [online], [cited 4 September 2016]. Available from Internet: http://www.mdps.gov.qa/en/knowledge/ Publications/Other/Census\%202015.pdf

MDPS. 2016. Population and social statistics. Ministry of Development Planning and Statistics [online], [cited 4 September 2016]. Available from Internet: http:// www.mdps.gov.qa/en/statistics/Statistical\%20Releases/ Population/Population/2015/1_Population_2015.pdf

Molotch, H. 1976. The city as a growth machine: towards a political economy of place, American Journal of Sociology 82: 309-332. https://doi.org/10.1086/226311

Narwold, A.; Sandy, J. 2010. Valuing housing stock diversity, in International Journal of Housing Markets and Analysis 3(1): 53-59.

Newmark, N. L.; Thompson, P. J. 1977. Self, space and shelter. San Francisco: Canfield Press.

Salama, A. M. 2011, Trans-disciplinary knowledge for affordable housing, Open House International 36(3): 7-15.
Salama, A. M. 2015, A socio-anthropological approach for exploring housing culture in contemporary Cairo, in A. Picone (Ed.). Culture Mediterranee Dell'abitare: Mediterranean housing cultures. Inhabiting the Future, Napoli: Collana, 128-137.

Salama, A. M.; Wiedmann, F. 2013. Demystifying doha: on architecture and urbanism in an emerging city. Surrey: Ashgate Publishing Limited.

Sinus Institute. 2016. Profile [online], [cited 4 September 2016]. Available from Internet: http://www.sinus-institut.de/en/ about-us/profile/

Veblen, T. 2009. The theory of the leisure class. Oxford World's Classics. Oxford: Oxford University Press.

Walters, G. 2006. Lifestyle theory: past, present and future. New York: Nova Science Publishers.

Wiedmann, F. 2012. Post-oil urbanism in the gulf: new evolutions in governance and the impact on urban morphologies. Stuttgart: SVH Verlag.

\section{ASHRAF M. SALAMA}

is an internationally-renowned academic and the 2017 UIA recipient of Jean Tschumi Prize for excellence in architectural education and criticism. The author and co-editor of nine books and numerous research papers published in the international peer-reviewed press, he is Chair Professor in Architecture and Head of the Department of Architecture, University of Strathclyde Glasgow, United Kingdom.

\section{FLORIAN WIEDMANN}

is an academic architect specialized in sustainable urbanism who has been working in research, practice and teaching since 2006. He is the author of various publications including two books, five book chapters and more than twenty articles in peer-reviewed journals. He is currently engaged as researcher at the Department of Architecture, University of Strathclyde, United Kingdom.

\section{HATEM G. IBRAHIM}

is an Associate Professor of Architecture at the Department of Architecture and Urban Planning at Qatar University. His research focuses on design processes and simulations, contemporary housing studies and architectural identity. In addition to his publications in scientific journals and symposiums, Dr Ibrahim was a keynote speaker and technical program committee of multiple international conferences and an editorial board member of many international journals. 